\title{
Effect of Sulphur and Boron Nutrition on Chemical Properties of Soil after Harvest of Soybean
}

\author{
S. Ravi ${ }^{1}$, R.L. Jadhav ${ }^{2}$, M.V. Ravi ${ }^{1}$ and Anand Naik ${ }^{1}$ \\ ${ }^{1}$ Departtment of Soil Science and Agricultural Chemistry, KVK, Bidar, \\ UAS, Raichur, Karnataka, India \\ ${ }^{2}$ Department of Agronomy, KVK, Bidar, UAS, Raichur, Karnataka, India \\ *Corresponding author
}

\begin{tabular}{|c|c|}
\hline & A B S T R A C T \\
\hline & \multirow{7}{*}{$\begin{array}{l}\text { An experiment was carried out during Kharif } 2014 \text { and } 2015 \text { at Krishi Vigyana Kendra } \\
\text { (KVK), Bidar, University of Agricultural Sciences, Raichur, Karnataka, India to assess the } \\
\text { sulphur and born nutrition on chemical properties of soil after harvest of soybean under } \\
\text { rainfed situation of Northern Karnataka. Results revealed that, among different rate of } \\
\text { sulphur and boron application along with recommended dose of fertilizer was significantly } \\
\text { not differed with respect to pH, electrical conductivity and organic carbon content in soil } \\
\text { after harvest of soybean. Further, Application of recommended dose of fertilizer }+12 \mathrm{~kg} \\
\mathrm{ZnSO} / \mathrm{ha}+30 \mathrm{~kg} \mathrm{Sulphur} / \mathrm{ha}+1.0 \mathrm{~kg} \text { Boron } / \mathrm{ha} \text { recorded significantly }(\mathrm{p}=0.05) \text { higher } \\
\text { available nitrogen }(283.5 \mathrm{~kg} / \mathrm{ha}), \mathrm{phosphorus}(30.5 \mathrm{~kg} / \mathrm{ha}) \text {, potassium }(407.5 \mathrm{~kg} / \mathrm{ha}) \text {, } \\
\text { sulphur }(22.82 \mathrm{~kg} / \mathrm{ha}) \text { and boron }(0.44 \mathrm{ppm}) \text { in soil after harvest of soybean and which was } \\
\text { on par with the application of recommended dose of fertilizer }+12 \mathrm{~kg} \mathrm{ZnSO} / \mathrm{ha}+30 \mathrm{~kg} \\
\mathrm{Sulphur} / \mathrm{ha}+1.5 \mathrm{~kg} \text { Boron } / \mathrm{ha}(21.5 \mathrm{q} / \mathrm{ha}) \text { compared to other treatments. It can be } \\
\text { concluded that, Application of recommended dose of fertilizer }(40: 80: 25 \mathrm{~kg} \mathrm{NPK} / \mathrm{ha})+12 \\
\mathrm{~kg} \mathrm{ZnSO} / \mathrm{ha}+30 \mathrm{~kg} \text { Sulphur } / \mathrm{ha}+1.0 \mathrm{~kg} \text { Boron/ha may increases the soil available } \\
\text { nutrients status after harvest of soybean under Northern Karnataka. }\end{array}$} \\
\hline & \\
\hline & \\
\hline $\begin{array}{l}\text { Organic carbon, } \\
\text { Sulphur, Boron, } \\
\text { Soybean }\end{array}$ & \\
\hline Article Info & \\
\hline $\begin{array}{l}\text { Accepted: } \\
07 \text { March } 2019 \\
\text { Available Online: } \\
10 \text { April } 2019\end{array}$ & \\
\hline & \\
\hline
\end{tabular}

\section{Introduction}

Recently Soybean [Glycine max (L.) Merrill] is being cultivated as an oilseed crop in India and it is recognized as "Golden Bean" due to its high nutritional value such as high quality protein (40-45\%), oil (18-20\%), mineral nutrients like calcium, iron and glycine. Apart from these, it is a good source of isoflavone which helps in preventing heart disease, cancer and HIVs. In India, the area under soybean cultivation was $10.18 \mathrm{~m}$ ha and the production was $12.28 \mathrm{~m} \mathrm{t}$ with productivity level of $1.21 \mathrm{t}$ per ha, though the crop has potential productivity of nearly $2,500-3,000$ $\mathrm{kg}$ per ha (Anon. 2016). Sulphur is involved in synthesis of fatty acid and also increased protein quality through the synthesis of certain sulphur containing amino acid such as cystine, cystein and methionine (Havlin et al., 1999). Boron deficiency occurs in highly leached sandy soils, acidic soils and soils low in organic matter and it plays an important role in nodulation, flowering, pollen 
germination, fruiting, seed setting and synthesis of protein and oil (Malewar et al., 2001).

Bidar District of Karnataka (India) is dominated by red lateritic and medium to deep black soils and these soils are poor in soil fertility due to deficiency of secondary and micronutrients. Soybean is one of the important oil seed crop and it is being grown in an area of 95,000 ha with a production of 33,250 thousand tonnes with an average productivity of $725 \mathrm{~kg} / \mathrm{ha}$. Since, the yields are low as compared to state average (950 $\mathrm{Kg} / \mathrm{ha}$ ). Intensive cropping, indiscriminate use of fertilizers and limited use of organic matter are the reasons for occurrence of sulphur and boron deficiency in the region which limits soil fertility and soybean yield. However, very meager information is available on response of soybean to sulphur and boron nutrition on chemical properties of soil after harvest of crop. Hence a field experiment was conducted to investigate the effect of sulphur and boron nutrition on chemical properties of soil after harvest of soybean in Northern Karnataka.

\section{Materials and Methods}

An experiment was carried out during Kharif 2014 and 2015 at Krishi Vigyana Kendra (KVK), Bidar, University of Agricultural Sciences, Raichur, Karnataka, India. The soil of the experimental field was clay loam, slightly saline $(\mathrm{pH} 8.32)$, high in organic carbon $(0.53 \%)$, available nitrogen $(285.0 \mathrm{~kg}$ $\mathrm{N} / \mathrm{ha}$ ), phosphorus (30 $\mathrm{kg} \mathrm{P}_{2} \mathrm{O}_{5} / \mathrm{ha}$ ), potassium (416 kg K $\left.\mathrm{K}_{2} \mathrm{O} / \mathrm{ha}\right)$, sulphur (8.3 ppm) and boron $(0.46 \mathrm{ppm})$.

The experiment was comprises of eight treatments viz., $\mathrm{T}_{1}$ : Absolute Control, $\mathrm{T}_{2}$ : RPP (40:85:25 kg NPK + $12 \mathrm{~kg} \mathrm{ZnSO}_{4}+20 \mathrm{~kg}$ Sulphur/ha), $\mathrm{T}_{3}$ : RPP + $0.5 \mathrm{~kg}$ Boron/ha, $\mathrm{T}_{4}$ : $\mathrm{RPP}+1.0 \mathrm{~kg}$ Boron $/ \mathrm{ha}, \mathrm{T}_{5}: \mathrm{RPP}+1.5 \mathrm{~kg}$
Boron/ha, T 6 : RDF (40:85:25 kg NPK/ha) + $12 \mathrm{~kg} \mathrm{ZnSO} / \mathrm{ha}+30 \mathrm{~kg}$ Sulphur/ha $+0.5 \mathrm{~kg}$ Boron/ha, $\mathrm{T}_{7}: \mathrm{RDF}+12 \mathrm{~kg} \mathrm{ZnSO} 4 / \mathrm{ha}+30 \mathrm{~kg}$ Sulphur/ha $+1.0 \mathrm{~kg}$ Boron/ha, $\mathrm{T}_{8}: \mathrm{RDF}+12$ $\mathrm{kg} \mathrm{ZnSO}_{4} / \mathrm{ha}+30 \mathrm{~kg}$ Sulphur/ha $+1.5 \mathrm{~kg}$ Boron/ha.

The experiment was laid out in randomized complete block design with three replications. Soybean variety JS 335 was grown at a row spacing of $45 \mathrm{~cm}$. Crop received recommended dose of nutrients @ 40:80:25: $\mathrm{kg} \quad \mathrm{N}: \mathrm{P}_{2} \mathrm{O}_{5}: \mathrm{K}_{2} \mathrm{O}$ per ha through urea, diammonium phosphate and muriate of potash, respectively. Sulphur and boron were applied as per treatment details through gypsum (18 $\% \quad \mathrm{~S})$ and borax (11 \% B), respectively. Soybean seed were inoculated with Bradyrhizobium japonicum culture @ 5 g per $\mathrm{kg}$ seed. The rainfall received during kharif 2014 and 2015 was $800 \mathrm{~mm}$ and $950 \mathrm{~mm}$, respectively. Other crop management practices were performed as per recommended package of practices. Available nitrogen in soil was determined by alkaline permanganate method as outlined by Subbiah and Asija (1959).

Available phosphorus in soil was determined by Bray's method as outlined by Jackson (1967). Available potassium in soil was determined by neutral normal ammonium acetate solution using flame photometer as outlined by Jackson (1967). The soil available sulphur was determined by turbidimetric method as outlined by Chesnin and Yien, 1950). The soil available boron was determined by Azomethine $\mathrm{H}$ method (Jackson, 1967). MSTAT was used for statistical analysis of data and means were separated using critical difference (CD) at $\mathrm{p}=0.05$. The data on weeds were transformed by square root transformation before being subjected to ANOVA (Gomez and Gomez, 1984). 


\section{Results and Discussion}

\section{Effect on chemical properties of soil}

The data on chemical properties of soil is presented in Table 1. Results revealed that, among different rate of sulphur and boron application along with recommended dose of fertilizer was significantly not differed with respect to $\mathrm{pH}$, electrical conductivity (EC) and organic carbon (OC) content in soil after harvest of soybean.

\section{Effect on soil available nutrients after harvest of soybean}

Available nitrogen, phosphorus and potassium in soil was significantly $(p=0.05)$ increased with different rate of application of sulphur and boron level (Table 2 and 3). Maximum availability of nitrogen $(283.5 \mathrm{~kg} / \mathrm{ha})$, phosphorus $(30.5 \mathrm{~kg} / \mathrm{ha})$ and potassium $(407.5$ $\mathrm{kg} / \mathrm{ha}$ ) in soil after harvest of soybean was observed in the treatment with the application of recommended dose of fertilizer $+12 \mathrm{~kg}$
$\mathrm{ZnSO}_{4} / \mathrm{ha}+30 \mathrm{~kg}$ Sulphur/ha +1.0 kg Boron $/ \mathrm{ha}(22.16 \mathrm{~kg} / \mathrm{ha})$ and which was onpar with the application of recommended dose of fertilizer $+12 \mathrm{~kg} \mathrm{ZnSO} / \mathrm{ha}+30 \mathrm{~kg}$ Sulphur/ha $+0.5 \mathrm{~kg}$ Boron/ha $(281.5,28.5$ and $383.0 \mathrm{~kg} / \mathrm{ha}$, respectively) compared to other treatments. The control treatment recorded significantly lower available nutrients in soil. These results are conformity with the findings of Meena et al., (2011).

Similarly, Sulphur availability in soil after harvest of crop was increased with increasing levels of sulphur application. Maximum available sulphur in soil (22.82 $\mathrm{kg} / \mathrm{ha})$ being associated with the application of recommended dose of fertilizer $+12 \mathrm{~kg}$ $\mathrm{ZnSO}_{4} / \mathrm{ha}+30 \mathrm{~kg}$ Sulphur/ha $+1.0 \mathrm{~kg}$ Boron/ha and which was on par with the application of recommended dose of fertilizer + $12 \mathrm{~kg} \mathrm{ZnSO} / 4 \mathrm{ha}+30 \mathrm{~kg} \mathrm{Sulphur} / \mathrm{ha}+1.5 \mathrm{~kg}$ Boron/ha (17.67 kg/ha) compared to other treatments. The control treatment recorded the lowest soil available sulphur.

Table.1 Effect of sulphur and boron nutrition on chemical properties of soil after harvest of soybean

\begin{tabular}{|c|c|c|c|c|c|c|c|c|c|}
\hline \multirow[t]{2}{*}{ Treatments } & \multicolumn{3}{|c|}{ pH } & \multicolumn{3}{|c|}{$\operatorname{EC}\left(\mathrm{dSm}^{-1}\right)$} & \multicolumn{3}{|c|}{ OC $(\%)$} \\
\hline & 2014 & 2015 & Pooled & 2014 & 2015 & Pooled & 2014 & 2015 & Pooled \\
\hline$T_{1}$ : Absolute control & 8.33 & 8.27 & 8.30 & 0.25 & 0.23 & 0.24 & 0.53 & 0.51 & 0.52 \\
\hline $\begin{array}{l}\mathrm{T}_{2}: \mathrm{RPP}(40: 80: 25 \mathrm{~kg} \\
\mathrm{NPK} / \mathrm{ha}+12 \mathrm{~kg} \mathrm{ZnSO} / \mathrm{ha}+ \\
20 \mathrm{~kg} \text { Sulphur/ha) }\end{array}$ & 8.35 & 8.30 & 8.32 & 0.30 & 0.27 & 0.29 & 0.58 & 0.53 & 0.56 \\
\hline $\mathrm{T}_{3}: \mathrm{RPP}+0.5 \mathrm{~kg}$ Boron $/ \mathrm{ha}$ & 8.39 & 8.35 & 8.37 & 0.31 & 0.32 & 0.31 & 0.58 & 0.57 & 0.57 \\
\hline$T_{4}:$ RPP + $1.0 \mathrm{~kg}$ Boron $/ \mathrm{ha}$ & 8.39 & 8.37 & 8.38 & 0.32 & 0.34 & 0.33 & 0.57 & 0.55 & 0.56 \\
\hline$T_{5}: R P P+1.5 \mathrm{~kg}$ Boron $/ \mathrm{ha}$ & 8.38 & 8.33 & 8.35 & 0.33 & 0.30 & 0.32 & 0.59 & 0.56 & 0.58 \\
\hline $\begin{array}{l}\mathrm{T}_{6}: \mathrm{RDF}(40: 80: 25 \mathrm{~kg} \\
\mathrm{NPK} / \mathrm{ha})+12 \mathrm{~kg} \mathrm{ZnSO} / \mathrm{ha} \\
+30 \mathrm{~kg} \text { Sulphur} / \mathrm{ha}+0.5 \mathrm{~kg} \\
\text { Boron/ha }\end{array}$ & 8.38 & 8.38 & 8.38 & 0.33 & 0.35 & 0.34 & 0.56 & 0.57 & 0.57 \\
\hline $\begin{array}{l}\mathrm{T}_{7}: \mathrm{RDF}+12 \mathrm{~kg} \mathrm{ZnSO} / \mathrm{ha} \\
+30 \mathrm{~kg} \mathrm{Sulphur} / \mathrm{ha}+1.0 \mathrm{~kg} \\
\text { Boron } / \mathrm{ha}\end{array}$ & 8.42 & 8.40 & 8.41 & 0.36 & 0.38 & 0.37 & 0.55 & 0.54 & 0.55 \\
\hline $\begin{array}{l}\mathrm{T}_{8}: \mathrm{RDF}+12 \mathrm{~kg} \mathrm{ZnSO} / \mathrm{ha} \\
+30 \mathrm{~kg} \mathrm{Sulphur} / \mathrm{ha}+1.5 \mathrm{~kg} \\
\text { Boron } / \mathrm{ha}\end{array}$ & 8.39 & 8.38 & 8.39 & 0.35 & 0.36 & 0.36 & 0.56 & 0.58 & 0.57 \\
\hline C.D. $(P=0.05)$ & NS & NS & NS & 0.02 & $\mathbf{0 . 0 3}$ & 0.03 & NS & NS & NS \\
\hline
\end{tabular}


Table.2 Effect of sulphur and boron nutrition on soil available nutrient status after harvest of soybean

\begin{tabular}{|c|c|c|c|c|c|c|c|c|c|}
\hline \multirow[t]{2}{*}{ Treatments } & \multicolumn{3}{|c|}{ Nitrogen $(\mathrm{kg} / \mathrm{ha})$} & \multicolumn{3}{|c|}{$\mathrm{P}_{2} \mathrm{O}_{5}(\mathrm{~kg} / \mathrm{ha})$} & \multicolumn{3}{|c|}{$\mathrm{K}_{2} \mathrm{O}(\mathrm{kg} / \mathrm{ha})$} \\
\hline & 2014 & 2015 & Pooled & 2014 & 2015 & Pooled & 2014 & 2015 & Pooled \\
\hline$T_{1}$ : Absolute control & 229 & 244 & 226.5 & 20 & 21 & 20.5 & 358 & 351 & 354.5 \\
\hline $\begin{array}{l}\mathrm{T}_{2}: \mathrm{RPP}(40: 80: 25 \mathrm{~kg} \mathrm{NPK} / \mathrm{ha}+ \\
12 \mathrm{~kg} \mathrm{ZnSO} 4 / \mathrm{ha}+20 \mathrm{~kg} \\
\text { Sulphur/ha) }\end{array}$ & 242 & 238 & 240.0 & 26 & 24 & 25.0 & 365 & 367 & 366.0 \\
\hline$T_{3}: R P P+0.5 \mathrm{~kg}$ Boron/ha & 265 & 254 & 259.5 & 22 & 21 & 21.5 & 370 & 371 & 370.5 \\
\hline$T_{4}: R P P+1.0 \mathrm{~kg}$ Boron/ha & 274 & 263 & 268.5 & 25 & 26 & 25.5 & 376 & 373 & 374.5 \\
\hline$T_{5}: R P P+1.5 \mathrm{~kg}$ Boron/ha & 271 & 263 & 267.0 & 23 & 25 & 24.0 & 381 & 370 & 375.5 \\
\hline $\begin{array}{l}\mathrm{T}_{6}: \text { RDF }(40: 80: 25 \mathrm{~kg} \mathrm{NPK} / \mathrm{ha})+ \\
12 \mathrm{~kg} \mathrm{ZnSO} / \mathrm{ha}+30 \mathrm{~kg} \\
\text { Sulphur} / \mathrm{ha}+0.5 \mathrm{~kg} \text { Boron } / \mathrm{ha}\end{array}$ & 284 & 279 & 281.5 & 28 & 29 & 28.5 & 384 & 382 & 383.0 \\
\hline $\begin{array}{l}\mathrm{T}_{7}: \mathrm{RDF}+12 \mathrm{~kg} \mathrm{ZnSO} / \mathrm{ha}+30 \\
\mathrm{~kg} \text { Sulphur/ha }+1.0 \mathrm{~kg} \text { Boron/ha }\end{array}$ & 288 & 279 & 283.5 & 30 & 31 & 30.5 & 405 & 410 & 407.5 \\
\hline $\begin{array}{l}\mathrm{T}_{8}: \mathrm{RDF}+12 \mathrm{~kg} \mathrm{ZnSO} / \mathrm{ha}+30 \\
\mathrm{~kg} \text { Sulphur/ha }+1.5 \mathrm{~kg} \text { Boron } / \mathrm{ha}\end{array}$ & 280 & 271 & 275.5 & 27 & 26 & 26.5 & 395 & 397 & 396.0 \\
\hline C.D. $(P=0.05)$ & 13.44 & 18.44 & 15.94 & 2.30 & 3.25 & 2.77 & 10.73 & 13.87 & 12.30 \\
\hline
\end{tabular}

Table.3 Effect of sulphur and boron nutrition on soil available nutrient status after harvest of soybean

\begin{tabular}{|c|c|c|c|c|c|c|}
\hline \multirow[t]{2}{*}{ Treatments } & \multicolumn{3}{|c|}{ Sulphur (kg/ha) } & \multicolumn{3}{|c|}{ Boron (ppm) } \\
\hline & 2014 & 2015 & Pooled & 2014 & 2015 & Pooled \\
\hline $\mathbf{T}_{1}$ : Absolute control & 8.15 & 8.10 & 8.13 & 0.39 & 0.37 & 0.38 \\
\hline $\begin{array}{l}\mathrm{T}_{2}: \mathrm{RPP}(40: 80: 25 \mathrm{~kg} \mathrm{NPK} / \mathrm{ha}+12 \\
\mathrm{kg} \mathrm{ZnSO} / \mathrm{ha}+20 \mathrm{~kg} \text { Sulphur} / \mathrm{ha})\end{array}$ & 10.66 & 10.13 & 10.40 & 0.45 & 0.44 & 0.44 \\
\hline T $_{3}:$ RPP + $0.5 \mathrm{~kg}$ Boron $/ \mathrm{ha}$ & 10.19 & 10.00 & 10.09 & 0.39 & 0.38 & 0.39 \\
\hline $\mathrm{T}_{4}: \mathrm{RPP}+1.0 \mathrm{~kg}$ Boron$/ \mathrm{ha}$ & 14.23 & 14.54 & 14.38 & 0.40 & 0.41 & 0.41 \\
\hline $\mathrm{T}_{5}: \mathrm{RPP}+1.5 \mathrm{~kg}$ Boron$/ \mathrm{ha}$ & 16.15 & 17.30 & 16.72 & 0.44 & 0.42 & 0.43 \\
\hline $\begin{array}{l}\mathrm{T}_{6}: \text { RDF (40:80:25 kg NPK/ha) + } 12 \\
\mathrm{~kg} \mathrm{ZnSO}_{4} / \mathrm{ha}+30 \mathrm{~kg} \mathrm{Sulphur} / \mathrm{ha}+ \\
0.5 \mathrm{~kg} \text { Boron } / \mathrm{ha}\end{array}$ & 16.95 & 17.55 & 17.25 & 0.42 & 0.44 & 0.43 \\
\hline $\begin{array}{l}\mathrm{T}_{7}: \mathrm{RDF}+12 \mathrm{~kg} \mathrm{ZnSO} / \mathrm{ha}+30 \mathrm{~kg} \\
\text { Sulphur} / \mathrm{ha}+1.0 \mathrm{~kg} \mathrm{Boron} / \mathrm{ha}\end{array}$ & 22.50 & 23.15 & 22.82 & 0.43 & 0.45 & 0.44 \\
\hline $\begin{array}{l}\mathrm{T}_{8}: \mathrm{RDF}+12 \mathrm{~kg} \mathrm{ZnSO} / \mathrm{ha}+30 \mathrm{~kg} \\
\text { Sulphur} / \mathrm{ha}+1.5 \mathrm{~kg} \text { Boron } / \mathrm{ha}\end{array}$ & 17.57 & 17.77 & 17.67 & 0.47 & 0.48 & 0.48 \\
\hline C.D. $(P=0.05)$ & 2.25 & 2.73 & 2.49 & 0.02 & 0.03 & 0.02 \\
\hline
\end{tabular}

The above results revealed that sulphur doses increased sulphur availability in soil after harvest of soybean. Similar findings are also reported by Ganeshamurthy (1996) who reported that application of sulphur significantly increased the sulphur availability in soil after the harvest of soybean. The highest boron availability in soil was achieved by the application of recommended dose of fertilizer $+12 \mathrm{~kg} \mathrm{ZnSO}_{4} / \mathrm{ha}+30 \mathrm{~kg}$ Sulphur/ha $+1.5 \mathrm{~kg}$ Boron/ha $(0.48 \mathrm{ppm})$ and which was closely followed by the application of recommended dose of fertilizer $+12 \mathrm{~kg}$ $\mathrm{ZnSO}_{4} / \mathrm{ha}+30 \mathrm{~kg}$ Sulphur/ha $+1.0 \mathrm{~kg}$ 
Boron/ha (0.44 ppm) compared to other treatments. The lowest soil available boron was observed in control plot. Similar results are also reported by Saxena and Nainwal (2010) and Singh, et al., (2013).

In conclusion, results indicated that, application of recommended dose of fertilizer + $12 \mathrm{~kg} \mathrm{ZnSO} / 4$ ha + $30 \mathrm{~kg}$ Sulphur $/ \mathrm{ha}+1.0 \mathrm{~kg}$ Boron/ha may enhances the soil available nutrient status and proved the improvement of soil fertility status in northern dry zone of Karnataka.

\section{References}

Anonymous. 2016. Director"s Report and Summary Tables of Experiments (2015- 2016), All India Coordinated Research Project on Soybean, Indore.

Chesnin, L and Yien, C.N., 1950. Proceedings of Soil Science Society of America. 15:149

Ganeshamurthy A N. 1996. Effect of sulphur application on seed and oil yield of Soybean. Journal of the Indian Society of Soil Science 44(2): 290-4.

Gomez, K.A. and A.A. Gomez, (1984). Statistical procedures for agricultural research (2 ed.). John wiley and sons, NewYork, 680p

Havlin L J, Beaton D J, Tisdale L S and Nelson L W. 1999. Soil fertility and fertilizers. Prentice hall of India, 6th ed., pp 220-27 and 319-346.

Jackson, M.L., 1967, Soil Chemical Analysis. Prentice Hall of India Pvt. Ltd., New Delhi, pp. 183-192.

Malewar G V, Kate S D, Waiker S L and Ismail S. 2001. Interaction effect of zinc and boron on yield, nutrient uptake and quality of mustard (Brassica juncia L.) on a typic Haplustert. Journal of Indian Society of Soil Science 49: 763-5.

Meena D S, Ram B and Tetarwal J P. 2011. Productivity, quality and profitability of soybean (Glycine max L.) as influenced by sulphur and boron nutrition. Soybean Research 9: 103108.

Saxena S C and Nainwal R C. 2010. Effect of sulphur and boron nutrition on yield, yield attributes and economics of soybean. Soybean Research 8: 7-12.

Singh, A. K., Singh, C. S. and Yadava, J. P., 2013, Response of Soybean to Sulphur and Boron Nutrition in Acid Upland Soils of Jharkhand. Soybean Research 11(2): 27-34

Subbiah, B.V. and Asija, C.L., 1959, A rapid procedure for estimation of available nitrogen in soils. Curr. Sci., 25:259260

\section{How to cite this article:}

Ravi, S., R.L. Jadhav, M.V. Ravi and Anand Naik. 2019. Effect of Sulphur and Boron Nutrition on Chemical Properties of Soil after Harvest of Soybean. Int.J.Curr.Microbiol.App.Sci. 8(04): 485-489. doi: https://doi.org/10.20546/ijcmas.2019.804.052 